\title{
Factors Associated with Health Personnel Performance in Tuberculosis Control Using “ACHIEVE” Model
}

\author{
Reni Dwi Pangestuti'), Sri Hernawati ${ }^{2)}$, Farida Wahyu Ningtyias 3) \\ 1)Masters Program in Public Health, Universitas Jember \\ 2)Faculty of Dentistry, Universitas Jember \\ 3)Faculty of Public Health, Universitas Jember
}

\begin{abstract}
Background: Tuberculosis (TB) remains a major public health problem in the world that causes morbidity and mortality. The role of health personnel is important in the implementation of lung TB control program. Health personnel performance that is not optimal can cause the TB case to remain high. Little is known about the factors affecting the performance of health personnel in Indonesia. This study aimed to examinethe determinants of health personnel performance in $\mathrm{TB}$ control using "ACHIEVE" model.

Subjects and Method: This was an analytic observational study with a cross-sectional design. The study was conducted in community health center in Jember, East Java. A sample of 45 health personnel of TB program implementation was selected for this study by simple random sampling. The dependent variable was health personnel performance, which included TB case finding, observation, and monitoring of TB patients. The independent variables were ability, clarity, help, incentive, evaluation, validity, and environment (ACHIEVE). The data were collected by questionnaire and analyzed by logistic regression in SPSS 16.

Results: Of all health personnel under study, 43 (93.4\%) had good ability, 75.6\% received positive organizational support, and $84.5 \%$ received appropriate evaluation. Health personnel performance was determined by ability $(\mathrm{OR}=2.98 ; \mathrm{p}=0.002)$, clarity $(\mathrm{OR}=1.18 ; \mathrm{p}=0.013)$, help $(\mathrm{OR}=2.98 ; \mathrm{p}=$ o.002), incentive $(\mathrm{OR}=0.98 ; \mathrm{p}=0.054)$, evaluation $(\mathrm{OR}=1.18 ; \mathrm{p}=0.013)$, and environment $(\mathrm{OR}=$ $0.80 ; \mathrm{p}=0.047)$.
\end{abstract}

Conclusion: Health personnel performanceis determined by ACHIEVE model, except validity which was not examine in this study.

Keywords: tuberculosis program, health personnel, performance, ACHIEVE model

\section{Correspondence:}

Reni Dwi Pangestuti. Masters Program in Public Health, Universitas Jember, Jl. Kalimantan I No.93, Krajan Timur, Sumbersari, Jember 68121, East Java. Email: renidwi730@gmail.com.

Mobile: 081224686538

\section{BACKGROUND}

$\overline{\text { Determinants of performance are deter- }}$ minants of the achievement of work in quality and quantity in carrying out their duties in accordance with the responsibilities given. The performance of health personnel in the Tuberculosis (TB) prevention program for Lung includes case finding activities, observation and monitoring of pulmonary of TB patients. The implementation of TB control needs serious efforts, because currently TB is still a public health problem in the world that causes high morbidity and mortality.

Data from the World Health Organization (WHO) 2016 Global Tuberculosis Report show that Indonesia is the second country with the highest number of TB cases in the world. East Java has the second largest number of sufferers after West Java in the number of TB case finding. Up to the district level, Jember was ranked second after Surabaya. The number of people with 
TB in Jember is 3,128 (East Java Provincial Health Office, 2016).

The fundamental problem that has resulted in higher TB cases is the low TB case finding rate and there are still many TB patients who have not received OAT treatment (Anti Tuberculosis Medication). The factors that influence the low case finding are the inadequacy of TB management in accordance with standards, both in case finding, treatment monitoring, recording and reporting (Permenkes RI, 2016). The discovery and cure of infectious TB patients will significantly reduce morbidity and mortality due to $\mathrm{TB}, \mathrm{TB}$ transmission in the community and also the most effective TB transmission prevention activities for the community.

Achieving goals in an organization depends on the performance of the members of the organization in carrying out their duties. There are many factors that affect the performance. Hersey,

Table 1. Characteristics of the study subjects

\begin{tabular}{llcc}
\hline Characteristics & \multicolumn{1}{c}{ Classification } & Frequency & \% \\
\hline Age (year) & $26-35$ & 7 & 15.6 \\
& $36-45$ & 17 & 37.8 \\
& $46-55$ & 20 & 44.4 \\
Gender & $56-65$ & 1 & 2.2 \\
& Female & 19 & 42.2 \\
Education & Male & 26 & 57.8 \\
& <Diploma & 4 & 8.9 \\
& Diploma (D3) & 22 & 48.9 \\
& Bachelor (S1) & 18 & 40.0 \\
Working period & Master/Doctor (S2/S3) & 1 & 2.2 \\
& <5 years & 5 & 11.1 \\
& $>5$ years & 40 & 88.9 \\
\hline
\end{tabular}

Based on the table 1, from a total of 45 study subject, it can be seen that the age group 46-55 years is the age group with the highest number of 20 (44.4\%). Gender groups are dominated by men with 26 (57.8\%). As many as 22 (48.9\%) study subjects were at Diploma III. Majority of
Blanchard, and Johnson formulated seven factors that influence the performance abbreviated as ACHIEVE (Ability, Clarity, Help, Incentive, Evaluation, Validity, Environment). High TB rates require good health personnel performance to reduce $\mathrm{TB}$ in Jember district.

\section{SUBJECTS AND METHOD}

This was a cross sectional study conducted in community health center in Jember, East. A sample of 45 health personnel of TB program implementation was selected for this study by simple random sampling. The data were collected by questionnaire and analyzed by a multiple logistic regression.

\section{RESULTS \\ 1. Characteristics of Study Subjects}

The data were obtained using questionnaires that have been distributed to health personnel implementing $\mathrm{TB}$ programs and are presented in Table 1. 
factors,itgoes into the good category for about $34(75.6 \%)$ respondents. In terms of incentives, respondents included in the good category were $33(73.4 \%)$. Validity factor which has a good category of 43 (95.6\%), and for the environment is 25 (55.7\%) which are in the sufficient category. Based on the results, most health personnel implementing TB programs have good performance.

\section{Multivariate Analysis}

Table 2. The results of a multiple logistic regression

\begin{tabular}{lcccc}
\hline \multirow{2}{*}{ Variable } & \multirow{2}{*}{$\mathbf{b}$} & \multicolumn{2}{c}{ 95\% CI } & p \\
\cline { 3 - 4 } & & Lower limit & Upper limit & \\
\hline Ability & -24.07 & -40.03 & -8.11 & 0.003 \\
Clarity & -15.78 & -26.64 & -4.91 & 0.004 \\
Help & -20.44 & -39.20 & -1.68 & 0.033 \\
Incentive & -17.85 & -34.08 & -1.63 & 0.031 \\
Evaluation & -19.26 & -49.55 & -3.96 & 0.021 \\
Environment & 5.36 & 10.96 & 84.75 & 0.011 \\
\hline
\end{tabular}

\section{DISCUSSIONS}

Based on the results of the analysis above, of the seven predictor variables, there were six variables that have a significant effect.

1. First variable (ability) showed that the better the ability (ability) of a person, the better the performance of that person. A person's work ability was one of the fundamental aspects for a worker to be able to survive in the field of work. Ability is a combination of skills and knowledge of someone. The result of this study was in accordance with a study by Nurdiana (2015) which stated that work ability has a positive and significant effect on employee's performance variables. Employees perceived that high work ability would further improve employee's performance. A theory of Hasibuan (2012) explained that performance is the result of the work that a person achieved in carrying out tasks which were charged to him/her, which were based on skills, knowledge, and experience. Based on this understanding,
Table 2 shows that ability $(b=-24.07 ; 95 \%$ $\mathrm{CI}=-40.03$ to $-8.11 ; \mathrm{p}=0.003)$, clarity $(\mathrm{b}=-$ 15.78; 95\% $\mathrm{CI}=-26.64$ to $-4.91 ; \mathrm{p}=0.004)$, help $(\mathrm{b}=-20.44 ; 95 \% \mathrm{CI}=-39.20$ to -1.68 ; $\mathrm{p}=0.033)$, incentive $(\mathrm{b}=-17.85 ; 95 \% \mathrm{CI}=$ 34.08 to $-1.63 ; \mathrm{p}=0.031)$, evaluation $(\mathrm{b}=-$ 19.26; $95 \% \mathrm{CI}=-49.55$ to $-3.96 ; \mathrm{p}=0.021)$, and environment $(b=5.36 ; 95 \% \mathrm{CI}=10.96$ to $84.75 ; \mathrm{p}=0.011$ ) were associated with health personnel performance in finding new TB cases. 
3. The third variable was help, this showed that most of the respondents stated that the facilities and quality of physical buildings in the workplace were not adequate. In the provision of equipments and materials (logistics) in the contact investigation, almost all respondents stated that they were adequate in terms of available extension facilities at the health center, and in supporting activities (forms, sputum pots, microscopes, reagents, etc.) of tuberculosis programs which available at the health center, and the majority of respondents stated that the availability of microscopy in finding new cases of AFB (+) was limited. The result of this study was in line with a study of Gustiana (2015) which stated that organizational support has a significant and direct effect on employee's performance and organizational commitment. Existing facilities in the health center were very helpful for officers in improving the performance or the results of their activities. This was supported by the idea of Notoatmodjo (2012), which stated that assistance or support facilities such as workplaces, transportation equipment, funds and the like were needed by the officers, especially the officers who worked in the field, however, in temporary observations, the equipments and facilities were very limited.

4. From the results of the incentive factor analysis, it was known that the rewards have a relationship with employee's performance. This was in accordance with the theory of Gitosudarmo (2008), which stated that this reward must be associated with the level of employee's performance. This mean that with the enhancement of rewards, it would encourage the employees to achieve higher work performance. A study by
Fandi (2017) revealed that incentive has a significant and positive effect on employee's performance. It was concluded that the higher the incentive, the higher the employee's performance at the company.

5. The next predictor was evaluation, which refer to coaching and feedback on daily performance as well as periodic reviews. An effective feedback process allowed employees to know how well the work that they have done. Another form of evaluation was in the form of supervision which carried out by the Health Office and health center staff on a regular and continuous ways include monitoring, coaching, problem solving, and follow-up. Supervision was also carried out by pulmonary TB officers to health cadres.

6. Validity factor in this study refer to the suitability of health personnel in doing contact investigations based on SOP. Based on the results of the study, the respondents stated that working as a pulmonary TB officer took up a lot of work time, the respondents stated that with double duty, the concentration of work was divided. Looking at the conditions in the field, the workload borne by TB program management officer was heavy, and many other tasks that were charged can have an impact on performance degradation. A considerable workload for TB program management officers brought undesirable consequences for the health care providers, which was the spread of health programs, especially those which were related to the coverage of new TB cases. With the workload, respondents stated that they agreed that the respondent's habit in providing reports to the Health Office of Jember District was not in time. 
7. The last factor was environment, which refer to the suitability of the work environment of health personnel in carrying out contact investigations. The environmental suitability was in the form of physical work environment and non-physical work environment. Based on the results of the study, most of the respondents stated that the $\mathrm{TB}$ service space was not appropriate, and the facilities in supporting their work were quite appropriate. While for nonphysical work environment, the answers of respondents were dominant, or all health personnel have a good working relationship with their partners in doing TB contact investigations.

Based on the results of the study, it can be concluded that ability, clarity, help, incentive, evaluation, and environment have a significant effect on the performance of health personnel in implementing $\mathrm{TB}$ programs.

\begin{tabular}{l}
\hline REFERENCES \\
\hline Ammons DN, Liston EG, Jones JA (2013). \\
Performance management purpose, \\
executive engagement, and reported \\
benefits among leading local govern- \\
ments. State \& Local Government \\
Review, 45(3): 172-179.
\end{tabular}

Annual Report (2017).Bending the curve ending TB 2030.WHO

Annual Report (2015). Challenge TB. United States Government: United States Agency for International Development (USAID).

Armstrong M (2000). Performance management: Key strategies and practical guidelines (2nd ed.). London, UK: Kogan Page

Askari R (2016). Quality of Working Life and Its Association with Organizational Performance: A Model Applied for Healthcare Workers. Biotech
Health Sci. inpress (inpress): e42050. Bangun W (2012). Manajemen Sumber Daya Manusia, Jakarta: Erlangga.

Beauté J, Dara M, Colombani, Ehsani S (2017). Tuberculosis surveillance and monitoring in Europe 2017. WHO.

Bititci U, Coccab P, Ates A (2015). Impact of visual performance management systems on the performance management practice of organizations. International Journal of Production Research. 1: 1-23.

Cho YJ, Lee JW (2012). Performance Management and Trust in Supervisors. Review of Public Personnel Administration, 32(3): 236-259

Eldridge, Dembkowski (2004). The Achieve Coaching Model. United Kingdom: Fenman Limited.

Farshadgohar N (2016). Study the Effect of Achieve Model on Employee Performance in Bank Melli Iran. The Caspian Sea Journal ISSN: 1578-7899, 10(1): 247-251.

Hersey P, Blanchard KH, Johnson DE (2008). Pengelolaan Perilaku Organisasi (ed. 9). Upper Saddle River, NJ: Prentice-Hall.

Hidayat (2009). Metode Penelitian dan Teknik Analisis Data. Jakarta: Salemba Medika

Infodatin Tuberkulosis (2016). Temukan Obati Sampai Sembuh. Jakarta: Kemenkes RI

Jacobsen CB, Andersen LB (2014). Performance management in the public sector: Does it decrease or increase innovation and performance. International Journal of Public Administration, 37(14), 1011-1023.

Karki B, Kittel G, Bolokon I, Duke T (2017). Active Community-Based Case Finding for Tuberculosis With Limited Resources. Asia Pacific Journal of Public Health, 29(1), 17-27 